\title{
Hindu Rashtra and Bollywood: A New Front in the Battle for Cultural Hegemony
}

\section{Nivedita Menon}

\section{(2) OpenEdition \\ Journals}

Electronic version

URL: http://journals.openedition.org/samaj/6846

DOI: $10.4000 /$ samaj.6846

ISSN: 1960-6060

\section{Publisher}

Association pour la recherche sur l'Asie du Sud (ARAS)

Electronic reference

Nivedita Menon, "Hindu Rashtra and Bollywood: A New Front in the Battle for Cultural Hegemony", South Asia Multidisciplinary Academic Journal [Online], 24/25 | 2020, Online since 11 November 2020, connection on 24 March 2021. URL: http://journals.openedition.org/samaj/6846 ; DOI: https://doi.org/ $10.4000 /$ samaj.6846

This text was automatically generated on 24 March 2021.

\section{(†)

This work is licensed under a Creative Commons Attribution-NonCommercial-NoDerivatives 4.0 International License. 


\title{
Hindu Rashtra and Bollywood: A New Front in the Battle for Cultural Hegemony
}

\author{
Nivedita Menon
}

1 A young, successful, Hindi film actor dies in tragic circumstances. What follows is a sensational real-life movie, scripted in the headquarters of Hindu Rashtra, as part of its larger campaign to control the cultural arena. ${ }^{1}$

2 Sushant Singh Rajput was found hanging in his bedroom in a Mumbai flat in June 2020, and it was initially declared as suicide by the Mumbai police. Within days however, the hashtag Justice for SSR started trending, and suddenly thousands of devoted and inconsolable fans had sprung up all over social media, all attacking "Bollywood" (the Bombay film industry) for its "nepotism" which had deprived a talented actor of work, driving him to suicide. "Boycott Bollywood" was a key theme in this frenzied outpouring of apparent grief. From this point, it escalated to claims that Rajput had been murdered, and that a drug cartel linked to Bollywood stars was involved in the crime. Soon these claims were all that one could see on social media, and on some Hindi, Marathi and English television channels, especially Republic and Times Now, which specialize in sensationalist and blatantly pro-Hindutva political reportage, including fake news (for one instance see Bajpai 2020).

3 A key figure in this campaign, with a relentless barrage of tweets about Rajput's death, is actor Kangana Ranaut, who entered the industry as an outsider, and now has a creditable body of work including the prestigious National and Filmfare awards under her belt. It is Ranaut who, in 2017, during a talk show hosted by quintessential "insider" film producer Karan Johar (from an industry family), challenged Johar directly about "nepotism"-the word was first used by her here-in the industry, including in his own productions, to his evident shock and embarrassment (Johar 2017).

Indeed, Ranaut was an exception on the show Koffee with Karan, which has almost exclusively featured generations of established film families engaging in cliquish gossip and insider jokes. Ranaut came into Hindi cinema from a small town, and by sheer 
talent made it to the top. She is an outsider not only to the industry, but also to polished English-speaking elite circles. While fluent in English, her earthy accent makes her stand out among film industry children who have attended, with one another, top schools in the country and abroad and some of whom in Koffee with Karan, refer to wellknown names in the industry as "Aunty" and "Uncle." Ranaut has also been publicly single for some years after a public breakup with an actor, which is irrelevant to our story. That is to say, she has had no visible protective male leaning over her and her persona is that of a smart, independent woman with a mind of her own, as is the case with several women in the industry. After that explosive interview, the term "nepotism" achieved iconic status, and pops up in almost any discussion on the Bombay film industry.

5 Another angle to Rajput's death was produced by Rajput's father, KK Singh, who accused Rajput's girlfriend of two years, Rhea Chakraborty (also an actor but just starting out) of lying about Rajput's mental health, which forced Rajput's therapist to issue a public statement that he "was suffering from bipolar disorder" (Quint Entertainment 2020). However, this was denied vehemently, and Singh accused Chakraborty of "abetment to suicide" (a punishable offence under the Indian Penal Code), and of cheating Rajput financially. The Enforcement Directorate (ED), which investigates financial crimes, registered a money laundering case against her, based on the complaint by Rajput's father. The case of Sushant's death was taken over from the Mumbai Police by the Central Bureau of Investigation (CBI). Meanwhile the ED requested that the Narcotics Control Bureau (NCB) join the investigation after its financial probe found that drugs were supplied to Chakraborty and Rajput. In September, Chakraborty was arrested by the NCB for procuring drugs for the latter. The investigation is still vigorously ongoing on this front, and some twenty people have been arrested on the drugs angle. Apart from Chakraborty and her brother, those arrested are some of Rajput's domestic staff and people identified by NCB as "drug dealers," who have been found in possession of hashish and marijuana, the quantity of which was not been revealed by the NCB (Pathak 2020).

6 We will now separate out some strands of the story of Rajput's death from the Hindu Rashtra narrative. The father's claims, to begin with, because it seems he is concerned exclusively with claiming Rajput's estate. He has made it a point to declare publicly that he is Rajput's only legal heir and, in addition to his two daughters, Rajput's only family, thus excluding Chakraborty from any financial claims that she might make (Gupta 2020).

7 We will also not enter into the misogynist and horrific attacks on Chakraborty in social media by the army of "SSR fans," and on television channels (apart from noting that misogyny is inextricably woven into Hindutva tactics); nor into the prejudice and ignorance (and in the case of Rajput's family, shame) surrounding mental illness and depression that have come to the fore. Pallavi Paul has addressed these two issues with compassion and sharp insight (Paul 2020).

8 A third element we will omit from discussion is that of impending state assembly elections (in Bihar, where Rajput was from; and in Bengal, where Chakraborty is from), the milking of Rajput's death by BJP as his champion, the corresponding villainization of Chakraborty and the equal and opposite reactions from other parties. This is a relatively familiar tactic in Indian politics that is not worth discussing further here (Ray 2020; Press Trust of India 2020a). 
We will focus in this essay only on how Rajput's death has been mobilized as part of a larger Hindutva campaign to purge the Bombay film industry of (or to tame)-the Muslims who dominate it; its regrettable tendency towards cultural syncretism; and most importantly, the voices in the industry that have been strongly speaking up against the politics of Hindu Rashtra since 2014. It hardly bears noting that the industry is also very wealthy, and the ruling party has not shown any aversion whatsoever towards controlling sources of wealth generation for itself (Press Trust of India 2020b).

There are three elements we must focus on in order to understand how Rajput's death was made to perform a role in Hindutva's ongoing push to control the cultural domain.

\section{Kangana Ranaut, BJP and Shiv Sena}

11 A quick background on these two parties in Maharashtra is required to locate Ranaut's role in the current potboiler. Shiv Sena and BJP have had a thirty year old political alliance in Maharashtra but despite being part of the larger Hindutva configuration, they fell out after the Assembly elections in 2019, when Shiv Sena's claim to the post of Chief Minister was denied by BJP, the two parties having secured the largest number of seats. Several dramatic twists and turns later, Shiv Sena entered into an alliance with Nationalist Congress Party (NCP) and Indian National Congress, Uddhav Thackeray of Shiv Sena becoming Chief Minister (India Today Web Desk 2019). Currently therefore, BJP and Shiv Sena are antagonists in the political arena, with BJP having the upper hand, being in control of the central government. Although the Shiv Sena has been content to act as junior partner to BJP since the late 1970s in pursuit of a more panIndian role, there are clear conflicts between its regional, Marathi-speaking and Maratha-Kunbi-Koli support base, and BJP's increasingly evident, RSS-driven North Indian Brahminical politics. For instance, Shiv Sena has for some time now publicly opposed vegetarianism and "gau rakshak"(cow protection) ${ }^{2}$ politics (Ghadyalpatil 2016; Kumar 2019) and demanded reservations for "lower" caste Kolis (fisher community) and Dhangars (shepherds) along with "upper" caste Marathas (Press Trust of India 2018). The RSS on the other hand, has often made public statements against caste-based reservations.

In the context of Rajput's death, the decisive shift in the investigation into Rajput's death, from the Mumbai Police to CBI, ED and NCB, signals that the central government is taking control, the state government is being marginalized (as well as the police who are under the authority of state governments). This shift enabled the larger narrative required by Hindutva politics, linking Rajput's death to the allegedly morally corrupt and degenerate, inbred, Bombay film industry, which needed to be cleaned out. Shiv Sena on the other hand, has its own, independent, long-standing relationship with the Bombay film industry, and does not appreciate BJP trying to muscle into this domain. Shiv Sena's response to the narrative surrounding Rajput's death has thus been an unequivocal defense of the film industry as Maharashtrian-founded by the Maharashtrian Dadasaheb Phalke. Mumbai as a city and the film industry in particular, being celebrated as offering work to lakhs of people from all over the country, regardless of religion and family background.

13 An editorial in Saamna, Shiv Sena's official newspaper, said: "All these people have always been grateful to the city and the state which allowed them to chase their dreams and make it big. They have never betrayed Mumbai but have also contributed 
to the growth of the city" (Press Trust of India 2020c). This marks a break, however temporary, with its previous nativist, Hindutva and narrowly nationalist politics. Regarding the last, it is interesting that this editorial approvingly cites the fact that Mumbai film artistes have been awarded the highest honors of the Indian government as well as of Pakistan. When Dilip Kumar accepted the Nishan-e-Imtiaz, Pakistan's highest civilian award in 1996, Shiv Sena had protested vociferously, and the personal relationship between Balasaheb Thackeray, the patriarch of Shiv Sena, and the actor, had soured (Holla 2009).

The battle lines are thus redrawn today in an unusual manner in Maharashtra. BJP pursuing an RSS scripted Hindutva agenda, finds itself in conflict with its former ally Shiv Sena, running a government with anti-BJP parties. But more significantly, Shiv Sena's Hindutva politics are currently playing a backseat role to its Maharashtrian identity, defined now in non-nativist terms, with Mumbai presented as the magic city that draws people from all over the country, their regional and religious identities irrelevant to success in Mumbai: "Those who come to Mumbai to try their luck in this industry first stay on the footpath and then shift to Juhu, Pali Hill and Malabar Hill to build their bungalows" (Press Trust of India 2020c). In this scenario, Kangana Ranaut and BJP have publicly displayed their allegiance to each other. Ranaut, who is from an old Congress family (her grandfather was a Congress MLA), moved conspicuously close to the ruling party after its election victory in May 2019. She celebrated the election results, saying on her "Team Kangana Ranaut" page: "What Modi Ji stands for are very strong set of ideas, vision and strength of human ambition. It needs a headstrong nation to be in sync with future possibilities of greatness" (Hindustan Times Entertainment Desk 2020).During the anti CAA protests that started in December 2019, she condemned those who were "instigating violence in the name of democracy." These people are still hung up on the "pre-Independence era," she said (Asian News International 2019). Earlier, in an interview she lashed out at celebrities of her industry as "sissies and cowards" for not speaking up against the violence. She accused them of being concerned only with their own privileged lives, and for "thinking that they are above the nation, they're above the people" (Hindustan Times Correspondent 2019). What is noteworthy is that many well-known names of the film industry had in fact publicly supported the peaceful protests against the CAA and condemned police violence against the protesters (Pathak 2019). Ranaut, both by referencing the violence as coming from the protesters, and through the disparaging reference to the "preIndependence era" (when Congress held the reins) was explicitly bolstering the government narrative.

Shiv Sena on the other hand, has been ambivalent regarding the CAA, voting in favor in the Lok Sabha, but refraining from backing the legislation in the Rajya Sabha. Between January and February 2020, Uddhav Thackeray first said it would lead to an "invisible partition" in India, but later an editorial in Saamna supported the CAA, while rejecting the NRC (Deshpande 2020). However, in August 2020, a Saamna editorial severely criticized the police violence on anti CAA students of Jamia Milia in Delhi: "If police uses guns on unarmed students, is not this just like what was done at Jallianwala Bagh? BJP has now lost any moral right to talk about the 1984 Sikh riots" (Ghoge 2020). Meanwhile after Rajput's death, in a rapid exchange of tweets, Ranaut emerged as a powerful BJP protégé. A BJP MLA in the Maharashtra Legislative Assembly tweeted in her support, saying that the Maharashtra government and the Mumbai Police should provide her protection after her "expose" on the "Bollywood-drug mafia" nexus. 
Ranaut tweeted in response, "Thank you for your concern sir, I am actually more scared of Mumbai police now than movie mafia goons..."

At this, Shiv Sena leader, Sanjay Raut (also editor of Saamna) took umbrage: “We kindly request her not to come to Mumbai. This is nothing but insult to Mumbai police. The Home Ministry should take action over it."

Ranaut took this as a direct threat to her personal safety and compared Mumbai to "Pakistan occupied Kashmir": "Sanjay Raut Shiv Sena leader has given me an open threat and asked me not to come back to Mumbai, after Aazadi graffities in Mumbai streets and now open threats, why Mumbai is feeling like Pakistan occupied Kashmir?" (Deshpande, A. 2020).

18 Almost immediately, the Union Home Ministry provided Y Plus security to Ranaut, supposedly on the assessment of intelligence agencies regarding her safety in Mumbai (Special Correspondent 2020). Within a couple of days after this, the Brihanmumbai Municipal Council (controlled by the Shiv Sena) started demolition of parts of Ranaut's office in Mumbai after issuing notice to her on structural violations; she went to court, and Bombay High Court pulled up BMC and stayed the demolition (HT Correspondent 2020).

19 At the time of writing this, there are conflicting reports surrounding Ranaut's mother having joined BJP.

Thus, Kangana Ranaut's generalized antagonism towards big names of the Bombay film industry has evidently been redeployed since May 2019, in some mutual arrangement between BJP and Ranaut. This antagonism now goes beyond nepotism and invokes the damning term anti-nationalism, which, as seen in action in Hindu Rashtra since 2014, means "critical of the government, BJP or RSS." Ranaut's recent attack on Karan Johar was for anti-nationalism, because of his film on a woman Indian Air Force officer triumphing against a sexist system (DNA Web Team 2020 a). There were objections to being projected in a "poor light" from the Air Force, and Ranaut joined in, adding that Johar "supported Pakistan during Uri battle and now antinational film against our Army" (Web Desk 2020).

21 In this process of emerging as nationalist and pro-Modi, Ranaut has no compunctions in viciously attacking much younger "outsiders" with no patrons, especially women actors like Swara Bhasker and Richa Chaddha, equally acclaimed for their talent, outspokenly feminist and uncompromisingly anti-Hindutva.

\section{\#JusticeforSSR groups}

Grieving and angry "fans" constitute the second element. Rajput entered Hindi films after a successful television career, and in seven years, headlined nine films that were both critically acclaimed and made their mark at the box office. He is not the best instance to illustrate the outsider marginalized because of nepotism. But overnight, it seemed there were hundreds of thousands of admirers who were not only devastated by his death but who precisely, in their multitudes, targeted the same individuals and nepotistic systems as responsible for his death. There were claims that he was dropped from several projects to accommodate insiders, but an interview with Rajput himself shows that at least some of these had to do with his prior commitments not sticking to schedule (India TV Entertainment Desk 2020). There were also indications that he was 
difficult to work with, which may have had to do with his poor mental health (Vasisht 2020; IANS 2020 b) but these were swallowed by an avalanche of denials that he was ill, both from his family and from the \#JusticeforSSR army.

Among the key targets of this army was Karan Johar, known to be close to Shahrukh Khan who has starred in several of his productions, and who has worked with Pakistani actors in his productions. In 2016, he came under tremendous pressure from Maharashtra Navnirman Sena (MNS, formed in 2005 after a split in the Shiv Sena) after an attack in Uri, supposedly by Pakistani terrorists. MNS threatened Pakistani actors in India, who left the country, and the Indian Motion Picture Producers Association (IMPPA) passed a motion to ban artistes from Pakistan till Indo-Pak relations were normalized (Press Trust of India 2016). Although he did not protest the ban, Johar has never lived down his pro-Pakistan image, as we saw with Ranaut's attack on him.

Another target is director Mahesh Bhatt, along with his daughter Alia, a top-ranking actor. Bhatt's mother was Muslim, and he is among those who have spoken out against Narendra Modi and the politics of Hindutva (IndiaToday.in 2014). Big names from film world families like Johar, Alia Bhatt, Kareena Kapoor (heir to the Kapoor legacy and also married to a Muslim actor, Saif Ali Khan, himself the bearer of a legacy), and Sonam Kapoor were trolled so viciously that they restricted comments on their social media. Sonam Kapoor wrote: "I understand that they are paid bots and people who are pushing a conservative right wing agenda. But right now is the time to speak about the lives lost at the borders and the lives affected by the lockdown. I'm turning off my comments" (Times of India.com 2020). BJP's IT Cell is infamous for producing targeted and systematic trolling by paid employees and bots (Chaturvedi 2016), and \#JusticeforSSR has all the hallmarks of an IT Cell campaign. Journalist Nidhi Suresh followed up with some of the groups involved in this hashtag and met three men (Suresh 2020). From her story, these men seem not so much bereaved fans of SSR, as people with other motivations, in addition to the misogyny and hatred towards Chakraborty in their social media feeds. One asked Suresh if she was anti-nationalist before meeting her, claiming to be nationalist himself. He later questioned her about her stand on the Citizenship Amendment Act and expressed his support for BJP. Another who in a YouTube video claimed to have met Rajput, denied this to the journalist, and interestingly, all his videos (which claim to expose "the dirty secrets of Bollywood" and which spewed abuse towards Chakraborty), to which Suresh included links in her article, have now been removed. His channel had two lakh subscribers. This person told Suresh he received "information" about the case from many quarters. The third was a member of Karni Sena, an organization claiming to represent "upper"-caste Rajputs, the caste to which Sushant Singh Rajput belonged. Karni Sena had led a violent campaign in 2017 against the film Padmavati claiming it was anti-Rajput. The film depicted a legend about the Mughal ruler Aurangzeb and a Rajput queen Padmavati (whose authenticity is disputed among historians) and the campaign against it was closely tied to Hindutva politics. One of the film makers targeted as part of the rotten nepotist film industry by \#JusticeforSSR is Sanjay Leela Bhansali, who made Padmavati (renamed as Padmavat as a concession to the protests). Bhansali too, was called for questioning by Mumbai Police after Rajput's death.

More "fan" activity-billboards with \#Justice for Sushant Singh Rajput were put up in many parts of the US including New Jersey and Chicago (CIEditor-Twinkle 2020). It seems unlikely that such an expense could have been undertaken by mere fans, and of a 
mid-level star at best, and the speculation cannot help but cross one's mind that USbased BJP-supporting organizations had something to do with it. (One of the billboards, in Hollywood, was taken down by the company that put it up, stating that they would not be part of a "smear campaign against a woman.") Indications of BJP IT-Cell involvement in the campaign are evident also because the Mumbai Police cyber unit has identified more than 80,000 fake accounts on social media platforms from various countries in Asia and Europe, all created on the day of Rajput's death, and that seek to discredit their official investigation (Ojha 2020).

Or take this article (Team Pgurus 2020) celebrating justice for Rajput after the case was taken over by the CBI from the "dubious" probe by Mumbai police working under Maharashtra's "controversial coalition government." The story precisely targets Shiv Sena and supports BJP, and all the other stories on this site take the government (and Hindutva) line-on Amnesty International (which shut down in India after escalating harassment by the government for alleged financial irregularities), on violence by anti CAA protesters, allegations of corruption against Congress leader Chidambaram and the leader of the Muslim organization Tablighi Jamat, and so on.

The troll army descended on every on-line article on Hindi cinema, even those not even remotely related to Rajput's death, with thousands of abusive comments on nepotism and drugs in the Hindi film industry, calling for justice for SSR, abusing Chakraborty, and urging people to \#BoycottBollywood.

There is no doubt whatsoever that this is a concerted campaign by the BJP IT Cell and BJP controlled media, and does not signify a general loss of popularity of the Bombay film industry, as some commentators fear (Sanghvi 2020).

It is another matter that the saturation of media spaces with this narrative tapped into a more expansive and nebulous terrain-into existing wellsprings on all sides, of misogyny; casteism (Ranaut equated nepotism with reservations); fear of women from "other" communities controlling their lovers to the detriment of the man's family; and the generalized trust deficit in institutions like the police, CBI, and ED, with a history of being used as instruments of political vendetta by whichever government is in power. ${ }^{3}$

\section{The "drug cartel"}

This is the third element in the Hindutva narrative. Rajput's death has now been ruled as a suicide by a six-member team of forensic doctors of the All India Institute of Medical Sciences (AIIMS) and the CBI's investigators have reached the same conclusion after their reconstruction of the incident. A forensic audit of Rajput's bank accounts has not thrown up anything to suggest that Rhea Chakraborty could have pushed Rajput to suicide for financial gain (Tiwary 2020). These developments should close the case now, had it really been about Rajput's death.

But rather, according to the journalist cited above, "CBI, sources said, is now focusing on the gamut of reasons that could have led to the actor taking his own life: any role played by Chakraborty; professional rivalry and nepotism in Bollywood; effect of drug abuse and Rajput's mental health" (Tiwary 2020).

The focus is now on drugs and a "drug mafia" with which the film industry and specific individuals are supposedly connected. While Chakraborty was granted bail by the Bombay High Court after a month in custody, soon after the AIIMS report, in October 
2020 , the court holding that she is not a drug dealer, the "drug mafia" angle has been used to drag in for questioning, a number of actors. A senior NCB official "familiar with the investigation" anonymously told a journalist that the NCB has been led to:

Large drug organisations and entities in Amritsar and Pakistan supplying cocaine and other hard drugs to Mumbai, and to Bollywood. While the NCB is working on tracing the backtrail from consumer to peddler to supplier to those controlling the trade, the emerging picture is one that threatens to roil Bollywood with past and present A-listers and others showing up on the radar of the agency. (Gupta 2020)

Prominent among these A-listers is Deepika Padukone, who visited Jawaharlal Nehru University in Delhi in January 2020, to attend a solidarity meeting called after armed thugs attacked students and faculty on campus. Her silent presence at the meeting made headlines, naturally, and she became the target of vicious trolling and calls to boycott her films. After Rajput's death, Padukone was questioned for five hours by the $\mathrm{NCB}$, and several other women actors were also questioned for many hours, among them Saif Ali Khan's daughter Sara.

The drugs claim may now be the route for a thorough purge of the Bombay film industry. The declaration of an ongoing, open investigation is a message being sent out to the Bombay film world. No more returning of awards to protest against government policies, no more statements against lynchings, CAA or rapes and murders of Dalit women. Anyone at all can be pulled in for questioning on drug use and drug peddling, and anyone at all can be jailed. Yes, the courts will most probably release the arrested individual eventually, for there may be no case, but they would have been in jail for a month or more, as Chakraborty was. The "process is the punishment," as political activists have learnt long ago. While the claims are of international drug traffickers and their links to the Bombay film industry, the actual arrests, as mentioned earlier, have been of people found in possession only of hashish and marijuana, in amounts the NCB did not disclose to the media, so presumably too small to boast of a "drug haul."

However, the threat is enough. The intimidation seems to have worked on some. Karan Johar, whose only misdeed was working with Pakistani actors, but who has otherwise not shown any inclination to buck the regime, has recently gone out of his way to obsequiously address the Prime Minister on Instagram, regarding an initiative by some film directors:

Drawing inspiration from our Honorable Prime Minister from whom we also seek sustained guidance, we the members of film fraternity are privileged to announce our plan to celebrate the $75^{\text {th }}$ year of Independence. Many more creative contributors will be joining us in the times to come. Watch this space for more!

(Not that everyone is equally intimidated. An acclaimed younger actor from the Malayalam film industry, Parvathy Thiruvothu-with one Hindi film, an outspoken feminist and one of the founders of the Women in Cinema Collective-responded to Johar's post with a single word sticker-“YUCK") (DNA Web Team 2020b). 


\section{RSS and the cultural domain}

As more information emerges about the frenzied attack on evil Bollywood, the role of BJP is becoming clearer. A study of social media content between June and September 2020 by a team led by Microsoft researcher Joyojeet Pal shows a pattern in which BJP pushed the narrative about Rajput's murder in order to discredit Shiv Sena and the Maharashtra government, as well as the Mumbai Police (Daniyal 2020).

Meanwhile, the Mumbai Police has opened an investigation into the TRPs (Television Rating Points) claimed by three television channels, two Marathi channels and Republic $T V$ (known to be all but an official BJP channel). The Mumbai Police spokesperson claimed to have evidence that the media organizations bribed economically poor households being metered to keep these specific channels switched on all the time even if they were not watching. "If you see the data, poor uneducated households that don't speak English were watching only English TV channels," he said (Gupta and Jain 2020). The crackdown at this time on what could really be a scam is clearly part of the feud between BJP and Shiv Sena.

However, this is only a small part of the picture. It would be a mistake to understand the frenzy unleashed upon Rajput's death solely as a power play between two political parties, especially as they are both part of the larger Hindutva ecosystem. The RSS has a much larger agenda, of which a purge of Bollywood is a part, and it seems BJP is the weapon to affect that purge.

There are two views within the RSS on the BJP-Shiv Sena feud, one holding that the Shiv Sena has abandoned Hindutva; the other, that this is precisely the dispensation VD Savarkar was working towards, when both the ruling party and the Opposition work towards Hindutva, especially as "Shiv Sena's cadre is imbibed with the spirit of Hindutva" (Iyer 2019). The direction the Shiv Sena is taking will only become clearer in the long term, but it seems at present to be re-crafting Hindutva along more inclusive lines, which could resemble Congress's soft Hindutva secularism. And this may not be only because of the exigencies of coalition politics, but because it wants to present a new kind of Hindutva politics, compatible with its Maharashtrian regionalism, which it claims to be real Hindutva.

In March 2020, top Shiv Sena leader Kishore Tiwari, President of the Vasantrao Naik Sheti Swavlamban Mission (VNSSM), wrote an open letter to the RSS-not his first one. In fact, he expresses the apprehension that his frequent missives questioning RSS support of BJP could lead to his expulsion from the RSS, a risk he is willing to take to protect Bharat Mata. This letter, as reported by news agencies, requests RSS to rein in its "Frankenstein's Monster," BJP, which resorts to "spreading the anti-Muslim poison, Pakistan, Bangladesh, fuel communal riots, etc." whenever Hindus question its wrongheaded policies. "The Hindus are now awake and that's why BJP is losing sleep," he is quoted as saying in the letter.

The immediate context was the announcement in the Maharashtra Legislative Council by Shiv Sena's coalition partner NCP's Nawab Malik, the state's Minorities Affairs Minister, of a forthcoming law to give a five percent quota to Muslims in education. Tiwari's letter characterized the opposition of BJP and some other "alleged Hindutva" groups to this as "anti-nationalist" and contradictory to the efforts of RSS and Prime Minister Modi to "bring minorities and deprived class people into the social 
mainstream for the economic development." RSS tenets, said Tiwari, are that "Hindutva is a culture, all religions have different mode and doctrine and all should be given equal respect and opportunity to enjoy full liberty and economic status." Tiwari also referenced "the legacy of social, communal and religious harmony left by Chhtrapati Shivaji Maharaj." BJP's going "on rampage with CAA-NRC-NPR, earns the RSS a bad name," he said. All communities, especially minorities, are an integral part of India and have sacrificed more than the so-called Hindu leaders, so the RSS must "bring its own big and small monsters into the bottle and discipline them" (IANS $2020 \mathrm{a}$ ).

41 No response from the RSS to this letter has been reported so far, but two things are clear: that there are rival claims to Hindutva (See also Sinha 2016), and that Hindutva has been mainstreamed in Indian politics. One clear indicator of the latter is the shift in political discourse, from the accusation of "pseudo secularism" by BJP against Congress and Left parties, to the accusation of pseudo Hindutva against BJP. Hindutva is the new North of the political compass, at least for now, with Tiwari's articulation of Hindutva being distinctly marginal as compared to BJP's. In its current form, since 2014 and more so since May 2019, Hindutva politics is openly Hindu supremacist and Islamophobic, but the Shiv Sena seems to be distancing itself from this version.

Returning to the Bombay film industry then, we must see the attack on it as part of the larger concerted move by the RSS to control and purge spaces seen as either controlled by "left liberals" or as syncretic and unamenable to Hindu-Muslim polarization. The RSS narrative-amplified by the government, police, social media and pliant television channels and newspapers-links Urban Naxals and Jihadis (Leftists and Islamist terrorists) in every such instance.

43 Non-endogamous marriage was the earliest target, through the term "love jihad" and the relentless pursuit by RSS linked organizations aided by police and often courts, of Hindu-Muslim marriages.

Universities have been under attack since 2014, as spaces of critical thinking, through tactics both coercive (using police and courts to quell student and teachers' freedom of expression), and administrative (making faculty appointments by manipulating procedure, disciplining faculty that raises questions). The new National Education Policy 2020 (NEP 2020) shows the clear imprint of RSS cultural values, and a blueprint to dismantle publicly funded education and encourage private capital in this sector, as well as to establish a tight ideological control over teaching and research (Menon 2020).

The large scale arrests of students, teachers, academics, litterateurs, social activists and journalists for "instigating violence" in three particular events-the Delhi violence of 2020, the Bhima Koregaon Dalit congregation in 2018 and now in Uttar Pradesh after the rape and murder of a Dalit woman in Hathras-have all shown the same pattern, the targeting of those sections with the cultural capital to counter Hindu Rashtra and caste violence.

46 Allegations of a "UPSC ${ }^{4}$ Jihad" began to circulate on social media this year, and a television channel aired a teaser of a program that purported to prove a Muslim conspiracy to infiltrate these administrative services (Shaikh 2020).

The targeting of the Bombay film industry cannot be understood separately from this larger agenda of the RSS. One of the first indicators, we have come to realize since 2014, are WhatsApp messages that outline bizarre conspiracies, which gradually appear in police reports, government statements and in the media, in all seriousness. One such 
widely circulated WhatsApp message (difficult to date because forwarded so many times) claimed a "film jihad," whose command was handed over four decades ago, to "ideologically cunning thugs \& frauds in the mask of the Leftists."

Most of the message targets writers Javed Akhtar and Salim, whose scripts "never depicted a Muslim villain" even though "police records show that 80 percent of the criminals in Mumbai were Muslims." Akhtar, the message says, visited Pakistan for decades "in the pretext of Pakistani Mushaira seminars and conferences," never spoke against "the demonic havoc" wreaked by "Pakistani Muslim goons" on minorities, but "this is the same Javed Akhtar who opposed the CAA and was insisting to give India's citizenship to the Pakistani Muslim goons." The message ends with

But 7-8 years ago, the common man of this country got the platform of social media and the truth was told by the common man from that platform. (Now you know why Modiji encouraged digital media.) The idols of the Leftist devils which were standing straight, have started to be uprooted by the public [emphasis added].

Bombay film royalty Aamir Khan and Shahrukh Khan (both married to Hindu women) have both faced the brunt of social media violence for expressing their anxiety as Muslims, in the new, post-2014 India. Aamir Khan even lost a sponsorship due to social media pressure on the company (Bhatia 2020). AR Rehman referred to a gang working against him in Bollywood, as a result of which he had not been given work in Hindi films for a long while (Press Trust of India 2020d). While this has been interpreted by many Ranaut supporters as bolstering the nepotism narrative, it seems unlikely that an Oscar winning music director would need those types of connections. His Muslim identity appears more likely to be the reason for his being marginalized in recent years.

In short, Sushant Singh Rajput's death was clearly weaponized by BJP/RSS in this push to purge Bollywood. Presumably as a counter to Bombay, the BJP government in UP under Yogi Adityanath (an instance of the harshest version of Hindu Rashtra at this time), has announced the setting up of a Film City in the state, to be called Chalachitrapuram (DNA Web team 2020 c). Ranaut has welcomed this move, citing Akhanda Bharat (the unified larger India of RSS dreams), and looking forward to a "terrorism free" film industry, in which she defines terrorism quite expansively (Kumar 2020).

The battle for India is ongoing on many fronts, even over Hindutva itself. Pikchar abhi baaqi hai, mere dost $!^{5}$

\section{BIBLIOGRAPHY}

Asian News International. 2020. “Anti-CAA Protests: Not Correct to Instigate Violence in Name of Democracy, says Kangana Ranaut.” The Economic Times, December 24. Retrieved November 11, 2020 (https://economictimes.indiatimes.com/magazines/panache/anti-caa-protests-not-correctto-instigate-violence-in-name-of-democracy-says-kangana-ranaut/videoshow/72947453.cms). 
Bajpai, Shailaja. 2020. "How Not to Report: A Lesson from Republic TV, Times Now, ABP Covering Bandra Migrants.” The Print. April 16. Retrieved November 11, 2020 (https://theprint.in/opinion/ telescope/a-lesson-from-republic-tv-news-times-now-abp-bandra-migrants/402641/).

Bhatia, Sidharth. 2020. "What's Behind the Sudden Spate of Attacks on Bollywood?" The Wire, September 23. Retrieved November 11, 2020 (https://thewire.in/politics/bollywood-attackspropaganda-movies).

Chaturvedi, Swati. 2016. I am A Troll: Inside the Secret World of the BJP's Digital Army. Juggernaut, Delhi.

CIEditor-Twinkle. 2020. "Sushant Singh Rajput's Billboard Removed in Hollywood, American Company Refuses to Join 'Smear Campaign of a Woman.” Can India News, September 3. Retrieved November 11, 2020 (https://www.canindia.com/sushants-billboard-removed-in-hollywoodsister-shweta-blames-paid-pr/).

Daniyal, Shoaib. 2020 "Research Paper Shows how BJP Pushed the Sushant Singh Murder Conspiracy to Target Shiv Sena." Scroll.in, October 7. Retrieved November 11, 2020 (https:// scroll.in/article/975091/research-paper-shows-how-bjp-pushed-the-sushant-singh-murderconspiracy-to-target-shiv-sena).

Deshpande, Alok. 2020. "Kangana Ranaut Compares Mumbai to PoK, Draws Flak." The Hindu, September 4. Retrieved November 11, 2020 (https://www.thehindu.com/news/cities/mumbai/ kangana-ranaut-compares-mumbai-to-pok-draws-flak/article32518728.ece).

Deshpande, Haima. 2020. "Shiv Sena Flip-flop on CAA Continues, Now Uddhav Thackeray Says Law has been Misunderstood." The Print, February 5. Retrieved November 11, 2020 (https:// theprint.in/politics/shiv-sena-flip-flop-on-caa-continues-now-uddhav-thackeray-says-law-hasbeen-misunderstood/360084/

DNA Web Team. 2020a. "Kangana Ranaut Mocks Karan Johar, Questions Patriotism in his Films." Daily News and Analysis. August 16. Retrieved November 11, 2020 (https://www.dnaindia.com/ bollywood/report-kangana-ranaut-mocks-karan-johar-questions-patriotism-in-hisfilms-2837973).

DNA Web Team. 2020b. "Parvathy Thiruvothu Disapproves Karan Johar's Independence Day Project.” Daily News and Analysis October 5. Retrieved November 11, 2020 (https:// www.dnaindia.com/entertainment/report-parvathy-thiruvothu-disapprove-karan-joharindependence-day-project-2847617).

DNA Web Team. 2020c. "UP Film City: Yogi Seeks Suggestions from 25 Film Personalities, to Meet Soundarya Rajinikanth." Daily News and Analysis, September 22. Retrieved November 11, 2020 (https://www.dnaindia.com/india/report-uttar-pradesh-film-city-state-government-seekssuggestions-from-25-film-personalities-yogi-adityanath-to-meet-soundaryarajinikanth-2844484).

Ghadyalpatil, Abhiram. 2016. "Shiv Sena starts Cooking up Non-vegetarian Politics." Mint, August 11. Retrieved November 11, 2020 (https://www.livemint.com/Opinion/ MN5INFXEA0ayC6bJ600cAP/Shiv-Sena-starts-cooking-up-nonvegetarian-politics.html).

Ghoge, Ketaki. 2020. “Uddhav Thackeray's Jallianwala Bagh Dart at BJP is Shiv Sena's New Normal." Hindustan Times August 8. Retrieved November 11, 2020 (https:// www.hindustantimes.com/india-news/uddhav-thackeray-s-jallianwala-bagh-dart-at-bjp-is-shivsena-s-new-normal/story-N73mXuA1Z3Ycalb2sc2ApL.html). 
Gupta, Saurabh. 2020 “'I am Legal Heir, Family,' Declares Sushant Singh Rajput's Father.” New Delhi Television, August 20. Retrieved November 11, 2020 (https://www.ndtv.com/india-news/ sushant-singh-rajputs-father-kk-singh-says-i-am-legal-heir-family-2282178).

Gupta, Shishir. 2020 "Sushant Singh Rajput Death: NCB Probe Leads to Pak and Drug Cartels; Bollywood A-listers under Scanner." Hindustan Times, September 21.

Gupta, Saurabh and Sreenivasan Jain. 2020. "Republic TV Among 3 Channels Busted for Rigging Ratings: Mumbai Cops.” New Delhi Television October 9. Retrieved November 11, 2020 (https:// www.ndtv.com/india-news/republic-tv-among-3-channels-being-probed-for-trp-manipulationmumbai-police-2307106?amp=1\&akamai-rum=off).

Hindustan Times Correspondent. 2019. “Kangana Ranaut Lashes out at Bollywood Actors' Silence over CAA Protests, Calls Them 'Sissies, Cowards, Spineless.” Hindustan Times, December 18. Retrieved November 11, 2020 (https://www.hindustantimes.com/bollywood/kangana-ranautlashes-out-at-bollywood-actors-silence-over-protests-calls-them-sissies-cowards-spineless/ story-f6mcjF59uxIugksD3VzM3M.html).

Hindustan Times Entertainment Desk. 2020. "Kangana Ranaut Says Congress, BJP Offered her Election Tickets: 'I am Obsessed with My Work as an Artist.” Hindustan Times, August 15. Retrieved November 11, 2020 (https://www.hindustantimes.com/bollywood/kangana-ranautsays-congress-bjp-offered-her-election-tickets-i-am-obsessed-with-my-work-as-an-artist/storySek7LVfqNBHS0phCgsQBzL.html).

Holla, Anand. 2009. “Ill-health Ends 13-yr-old Feud." Mumbai Mirror, June 29. Retrieved November 11, 2020 (https://mumbaimirror.indiatimes.com/mumbai/cover-story/ill-health-ends-13-yr-oldfeud/articleshow/15935307.cms).

HT Correspondent. 2020. "BMC's Demolition of Kangana Ranaut's Office: All You Need to Know." Hindustan Times, September 9. Retrieved November 11, 2020 (https://www.hindustantimes.com/ mumbai-news/all-you-need-to-know-about-bmc-s-demolition-of-kangana-ranaut-s-office/storygCm1J7Y24dXgaxgj5RWW30.html).

IANS. 2020a. "Save Bharat Mata from Frankenstein's Monster BJP: Shiv Sena to RSS." The New Indian Express March 2. Retrieved November 11, 2020 (https://www.newindianexpress.com/ nation/2020/mar/02/save-bharat-mata-from-frankensteins-monster-bjp-shiv-sena-torss-2111115.html).

IANS 2020b. "Anurag Kashyap on Why He did not Work with 'Problematic' Sushant Singh Rajput." National Herald, September 9. Retrieved November 11, 2020 (https:// www.nationalheraldindia.com/films/anurag-kashyap-on-why-he-did-not-work-withproblematic-sushant-singh-rajput).

IndiaToday.in. 2014. "Modi is Communal, Should be Defeated, says Mahesh Bhatt." India Today, April 25. Retrieved November 11, 2020 (https://www.indiatoday.in/elections/uttar-pradesh/ story/dont-want-modi-as-pm-says-mahesh-bhatt-190458-2014-04-25).

India Today Web Desk. 2019. "Thackeray, first of his Clan, Takes Oath as Chief Minister of Maharashtra." India Today, November 28. Retrieved November 11, 2020 (https:// www.indiatoday.in/india/story/uddhav-thackeray-maharashtra-chiefminister-1623468-2019-11-28).

India TV Entertainment Desk. 2020. "Sushant Singh Rajput Dropped out of Half Girlfriend, Fitoor. Here's Why.” India TV, June 25. Retrieved November 11, 2020 (https://www.indiatvnews.com/ entertainment/celebrities/sushant-singh-rajput-drop-out-mohit-suri-half-girlfriend-replacedby-arjun-kapoor-628986) 
Iyer, Aishwarya S. “'It's Clear, Shiv Sena Abandoned Hindutva for Power': RSS Thinker” The Quint, December 2. Retrieved November 11, 2020 (https://www.thequint.com/news/politics/ maharashtra-govt-bjp-shiv-sena-fall-out-impact-on-hindutva-rss-congress-ncp-sena-alliance).

Johar, Karan 2017. “Saif Kangana Let It all Out.” Koffee with Karan. Episode 16, February 17. [videorecording]/ F. Allana and K. N. Menezes. Mumbai: Star World. Retrieved November 11, 2020 (https://www.hotstar.com/in/tv/koffee-with-karan/1525/saif-kangana-let-it-all-out/ 1000167379).

Kumar, Shiv 2019. “Milind Deora Plays ‘Vegetarian' Card against Shiv Sena in South Mumbai." The Tribune, April 6. Retrieved November 11, 2020 (https://www.tribuneindia.com/news/archive/ nation/milind-deora-plays-vegetarian-card-against-shiv-sena-in-south-mumbai-754290).

Kumar, Vineeta. 2020. “Kangana Ranaut Wants 'Terrorism Free' Film Industry after Yogi Adityanath's Announcement” India.com, September 19. Retrieved November 11, 2020 (https:// www.india.com/entertainment/bollywood-news-kangana-ranaut-wants-terrorism-free-filmindustry-after-yogi-adityanaths-announcement-4145896/).

Menon, Nivedita. 2020. "NEP 2020-Elitist and Corporatized Education Under Hindu Rashtra." Kafila, August 9. Retrieved November 11, 2020 (https://kafila.online/2020/09/08/nep-2020elitist-and-corporatized-education-under-hindu-rashtra/

Ojha, Suraj. 2020. "Sushant Singh Rajput Death Case: Over 80k Fake Accounts Created to Discredit Mumbai Police Probe.” Hindustan Times, October 5. Retrieved November 11, 2020 (https:// www.hindustantimes.com/mumbai-news/sushant-singh-rajput-death-case-over-80k-fakeaccounts-created-to-discredit-mumbai-police-probe/story-qjpqRUsgC95wBwshReLiyI.html).

Pathak, Ankur. 2019. “CAA: An Exhaustive List of All the Celebrities Who've Spoken Out in Support of Protests." Huffington Post, December 17. Retrieved November 11, 2020 (https:// www.huffingtonpost.in/entry/bollywood-celebrities-supporting-protest-cabact_in_5df8b4a0e4b047e888a3d358).

Pathak, Manish K. 2020. "Sushant Singh Rajput Death Case: NCB Arrests Six People from Mumbai, Goa." Hindustan Times, September 12. Retrieved November 11, 2020 (https://

www.hindustantimes.com/india-news/sushant-singh-rajput-death-case-ncb-arrests-six-peoplefrom-mumbai-goa/story-

hHOD1obTbUmatrqVlj1uzL.html\#: :text=In\%20its\%20ongoing\%20probe\%20linked,people\%20from\%20Mumbai\%20and\%20Goa.\&text=Th

Paul, Pallavi. 2020. "Sushant Singh: This Macabre Circus will Terrorise People into Covering up Mental Illness.” The Wire, September 5. Retrieved November 11, 2020 (https://thewire.in/women/ rhea-sushant-media-cbi-mental-health).

Press Trust of India. 2016. "Ajay Devgn Slams Salman Khan and Karan Johar for Supporting Pakistani Artistes.” Economic Times, October 8. Retrieved November 11, 2020 (https:// economictimes.indiatimes.com/magazines/panache/ajay-devgn-slams-salman-khan-and-karanjohar-for-supporting-pakistani-artistes/articleshow/54754564.cms?from=mdr).

Press Trust of India. 2018. "Shiv Sena Demands Reservation for Dhangars, Kolis with Marathas; Party Claims State will become 'Banana Republic' if all Communities Protest.” Firstpost, July 31. Retrieved November 11, 2020 (https://www.firstpost.com/india/shiv-sena-demands-reservationfor-dhangars-kolis-with-marathas-party-claims-state-will-become-banana-republic-if-allcommunities-protest-4858481.html).

Press Trust of India. 2020a. “Rhea Chakraborty's Arrest Proved Bengalis Soft Target of BJP: Bengal Leaders.” New Delhi Television, September 11. Retrieved November 11, 2020 (https:// 
www.ndtv.com/india-news/rhea-chakrabortys-arrest-proved-bengalis-soft-target-of-bjp-bengalleaders-2293634).

Press Trust of India. 2020b. "BJP got 64\% of Rs 2,513-cr Political Donations from Unknown Sources in FY19." Business Standard, March 10. Retrieved November 11, 2020 (https:// www.business-standard.com/article/politics/bjp-got-64-of-rs-2-513-cr-political-donations-fromunknown-sources-in-fy19-120031000111_1.html).

Press Trust of India. 2020c. "People Succeed in Bollywood With Talent, Not Religion: Shiv Sena." New Delhi Television, September 12. Retrieved November 11, 2020 (https://www.ndtv.com/indianews/shiv-sena-says-people-succeed-in-bollywood-with-talent-not-religion-2294518).

Press Trust of India. 2020d. “AR Rahman Claims there's a 'Gang' Working Against Him in Bollywood, Spreading 'False Rumours.” Firstpost, July 26. Retrieved November 11, 2020 (https:// www.firstpost.com/entertainment/ar-rahman-claims-theres-a-gang-working-against-him-inbollywood-spreading-false-rumours-8641511.html\#: :text=Entertainment-).

Purohit, Kunal. 2020. “Online Groups Stoked Anger over Sushant Singh Rajput's Death.” Article 14. October 1. Retrieved November 11, 2020 (https://www.article-14.com/post/online-groupsstoked-anger-over-sushant-singh-rajput-s-death).

Quint Entertainment. 2020. “Sushant's Therapist Going Public Gets Twitter Divided.” The Quint, August 22. Retrieved November 11, 2020 (https://www.thequint.com/entertainment/celebrities/ sushants-therapist-going-public-gets-twitter-divided).

Ray, Umesh Kumar. 2020. "Is the BJP Deriving Political Mileage out of the Sushant Singh Rajput Case?” The Wire, September 8. Retrieved November 11, 2020 (https://thewire.in/politics/bjpsushant-singh-rajput-bihar-elections).

Sanghvi, Vir. 2020. “The Real Whodunit in SSR Case Is Obvious, Isn't It.” New Delhi Television, October 7. Retrieved on November 11, 2020 (https://www.ndtv.com/opinion/the-real-whodunitin-ssr-case-is-obvious-isnt-it-by-vir-sanghvi-2306575).

Shaikh, Rais I. 2020. “Sudarshan TV's 'UPSC Jihad' Episode is an Assault Not Just on Muslims but on the UPSC Too.” The Wire, September 15. Retrieved on November 11, 2020 (https://thewire.in/ communalism/sudarshan-tv-upsc-jihad-muslims-civil-services).

Sinha, Rakesh. 2016. "A Melting Pot.” The Indian Express, March 4. Retrieved on November 11, 2020 (https://indianexpress.com/article/opinion/columns/a-melting-pot-2/).

Special Correspondent. 2020. "Home Ministry Grants Security Cover for Kangana Ranaut.” The Hindu, September 7. Retrieved on November 11, 2020 (https://www.thehindu.com/news/ national/home-ministry-grants-security-cover-for-kangana-ranaut/article32541553.ece).

Suresh, Nidhi. 2020. "Inside the Online Cult of \#JusticeforSSR." Newslaundry.com September 6. Retrieved on November 11, 2020 (https://www.newslaundry.com/inside-the-online-cult-ofjustice-for-SSR).

Team Pgurus. 2020. "Justice Delivered in the Sushant Singh Case. Meet the Heroes and Villains in Justice for Sushant Singh Rajput.” Pgurus, August 20. Retrieved on November 11, 2020 (https:// www.pgurus.com/justice-delivered-in-the-sushant-singh-case-meet-the-heroes-and-villains-injustice-for-sushant-singh-rajput/).

Times of India.com. 2020. "Alia Bhatt, Kareena Kapoor Khan, Karan Johar, Suhana Khan and Ananya Panday Limit Comments on their Instagram Posts amid Nepotism Row.” Times of India, June 23. Retrieved on November 11, 2020 (https://timesofindia.indiatimes.com/entertainment/ hindi/bollywood/news/alia-bhatt-kareena-kapoor-khan-karan-johar-suhana-khan-and-ananya- 
panday-limit-comments-on-their-instagram-posts-amid-nepotism-row/articleshow/

76522246.cms).

Tiwary, Deeptiman. 2020. "Sushant Singh Rajput Death Case: CBI Probe Matches AIIMS Find, No

Red Flags in Accounts Audit." The Indian Express. October 7. Retrieved on November 11, 2020

(https://indianexpress.com/article/india/sushant-rajput-case-cbi-probe-matches-aiims-find-nored-flags-in-accounts-audit-6705903/).

Vasisht, Vishnu. 2020 “Sushant Singh Rajput Suicide: 'Bollywood Insider' had made Shocking Revelations about the Actor Few Days Ago." The Scrbblr, June 14. Retrieved on November 11, 2020 (https://thescrbblr.in/sushant-singh-rajput-suicide-bollywood-insider-had-made-shockingrevelations-about-the-actor-few-days-ago/).

Web Desk, 2020. “Gunjan Saxena' Controversy: Kangana says Govt Should Take Back Karan Johar's Padma Shri.” The Week, August 18. Retrieved November 11, 2020 (https:// www.theweek.in/news/entertainment/2020/08/18/gunjan-saxena-kangana-says-govt-shouldtake-back-karan-johar-padma-

shri.html\#: :text=EDUCATION-,'Gunjan\%20Saxena'\%20controversy\%3A\%20Kangana\%20says\%20govt\%20should\%20take,back\%20Karan\%

\section{NOTES}

1. I would like to thank Ira Bhaskar and Aditya Nigam for comments on the draft of this essay.

2. Gau rakshak politics is the Hindutva campaign against cow slaughter, which is used to target Muslims as "cow killers." Several lynchings of Muslims since 2014 have been based on the false claim that the person was transporting cows to slaughter or had already done so. Since cow slaughter had already been banned in the states where the lynchings took place, this was never the case.

3. For a detailed investigation of the kind of surreal conspiracies that were alleged within social media circles, see Purohit (2020).

4. Union Public Service Commission.

5. An iconic line from the Hindi film Om Shanti Om (2007, Scriptwriter Mayur Puri), which means - "The movie is not over yet, my friend."

\section{ABSTRACTS}

This paper examines the weaponization by Hindu right-wing politics of the suicide of a young Hindi film actor in September 2020. It argues that his death was invoked in particular ways to sharpen the attack on the Bombay film industry as part of the larger concerted move by the RSS to control and purge spaces seen as either controlled by "left liberals," or as syncretic and unamenable to Hindu-Muslim polarization. In the course of this attack, some differences within the Hindutva camp have become evident, a phenomenon this paper examines closely. 
INDEX

Keywords: Bharatiya Janata Party, Shiv Sena, Bollywood, Sushant Singh Rajput

AUTHOR

NIVEDITA MENON

Jawaharlal Nehru University, Delhi. 